\title{
Seasonal Pattern of the Biogeochemical Properties of Mangrove Sediments receiving Shrimp Farm Effluents (New Caledonia)
}

\author{
Molnar $\mathbf{N}^{1,2}$, Marchand $\mathrm{C}^{1 *}$, Deborde $\mathrm{J}^{1}$, Della Patrona $\mathrm{L}^{3}$ and Meziane $\mathrm{T}^{2}$ \\ ${ }^{1}$ IRD, UR 206, UMR 7590-IMPMC, F-98848 New Caledonia, France \\ ${ }^{2}$ UMR Biology of Aquatic Organisms and Ecosystems, National Museum Natural History, CP 53, 61 Rue Buffon, 75231 Paris cedex 05, France \\ ${ }^{3}$ Départment of Lagons, Ecosystems and Sustainable Aquaculture (LEAD/NC), Ifremer, 101, Promenade Roger Laroque, Centre IRD, BP 2059-98846 Nouméa Cedex, \\ New Caledonia, France
}

\begin{abstract}
Coastal tropical shrimp farming may impact the adjacent ecosystems through the release of large quantities of effluents rich in nutrients. In New Caledonia, mangroves are considered as a natural biofilter to reduce impacts on the surrounding World Heritage listed lagoon. Our main objective was to understand the influence of effluent discharge on the biogeochemistry of mangrove sediments. A monitoring of the physico-chemical parameters of mangrove sediments was carried out during a whole year, including active and non active periods of the farm. The parameters studied were: i) benthic primary production (Chl-a concentrations), ii) physico-chemical parameters of sediments (redox potential, $\mathrm{pH}$, salinity, TOC, TN, TS, $\delta^{13} \mathrm{C}$ and $\delta^{15} \mathrm{~N}$ ), iii) concentrations of dissolved nitrogen, iron and phosphorus. A mangrove developing in the same physiographic conditions, presenting the same zonation, and free of anthropogenic input was used as reference. The concentration of benthic Chl-a measured at sediment surface in the effluent receiving mangrove was twice to three times that measured in the control zone whatever the season. We thus suggest that nutrients inputs significantly increased the phytobenthic production in the effluent receiving mangrove during the whole year, even after the cessation of discharges and because of natural seasonal dynamic of phytobenthos. Although the flow of surface OM was increased, the OM content at depth was not higher than in the control mangrove. However, the contribution of mangrove detritus to the sedimentary organic pool was higher probably as a result of higher density and much greater individual size of the mangrove trees. Unlike the control mangrove sediment, the effluent receiving mangrove sediment was not stratified, redox potential values were high and presence of $\mathrm{Fe}^{3+}$ was detected down to $50 \mathrm{~cm}$ depth, probably as a result of a larger root system, allowing a better sediment oxygenation and accentuated OM decomposition processes, and thus limiting ecosystem saturation.
\end{abstract}

Keywords: Shrimp farming; Effluents; Mangrove; Sediment biogeochemistry; New Caledonia

\section{Introduction}

Mangroves are tropical and subtropical ecosystems developing at the edge between land and sea. They extend over $140000 \mathrm{~km}^{2}$ of the coastal zone and over a latitudinal range of $30^{\circ} \mathrm{N}$ to $38^{\circ} \mathrm{S}[1,2]$. Mangroves are crucial both ecologically and economically, supporting a wide variety of ecosystem services [3-5]. For instance, mangroves are very efficient to trap suspended materials because of the density of their aerial roots, and also because it is a low energy environment [6]. Thus, they may act as a filter, retaining particles from watershed, and avoiding over-deposition in coastal waters. Because it is a highly active biogeochemical environment, several countries used them as natural biofilters to treat urban or aquaculture sewages. The annual economic values of mangroves, estimated by the cost of the products and services they provide, have been estimated to be USD 200,000-900,000 ha-1 [7]. Income related to fisheries undertaken by the presence of mangroves is estimated at $10,000 \$$ per hectare per year, with a high variability between areas and market value [8]. In addition, the value of biofilter functions ranges between US \$ $1193 \mathrm{ha}^{-1}$ year $^{-1}$ and US $\$ 5820 \mathrm{ha}^{-1}$ year $^{-1}$ [8]. Once mangroves covered more than $200,000 \mathrm{~km}^{2}$ [9]. Unfortunately, mangrove forests are among the most threatened global ecosystems [1013]. The destruction of the ecosystem takes place all-around the world, especially in emerging countries, where $90 \%$ of mangroves are located. Aquaculture accounts for $52 \%$ of mangrove loss globally, with shrimp farming alone accounting for $38 \%$ of mangrove deforestation $[12,14]$. World-wide, shrimp farming has increased almost exponentially since the mid-1970's due to short production cycles and their high product values, reaching a total annual production of over 2.3 billion tons in 2008 [15]. In tropical and sub-tropical zones, particularly in South America, Indonesia and Thailand, shrimp farms have been developed at the expense of mangrove forests, which are destroyed for the establishment of the rearing ponds [16]. In addition to the direct loss of mangroves during construction, shrimp farms also impact the adjacent mangroves through the release of large quantities of effluents rich in particulate and dissolved organic and inorganic nutrients [1719]. During a production cycle, it has been estimated that only 29 and $16 \%$, respectively, of total nitrogen and phosphorus added to the ponds as food and fertilizers inputs, is actually assimilated by shrimps [20]. In New Caledonia, shrimp farming is still a relatively small industry consisting of 19 farms with ponds covering 680 ha, with an annual production of 2,000 tons in 2006 [21]. In contrast to other parts of the World, there are no direct losses of mangroves due to shrimp farming, as local regulations prevent construction of farms within the mangroves themselves. Therefore, farms are built upstream of the mangrove forests within the salt-flats. However, ponds effluents are discharged into the adjacent mangroves, which are considered as a "natural biofilter", to

*Corresponding author: Marchand C, IRD, UR 206, UMR 7590-IMPMC, F-98848 New Caledonia, France, Tel: +33 637081531; E-mail: cyril.marchand@ird.fr

Received March 27, 2014; Accepted June 23, 2014; Published July 03, 2014

Citation: Molnar N, Marchand C, Deborde J, Della Patrona L, Meziane T (2014) Seasonal Pattern of the Biogeochemical Properties of Mangrove Sediments receiving Shrimp Farm Effluents (New Caledonia). J Aquac Res Development 5: 262. doi:10.4172/2155-9546.1000262

Copyright: (C) 2014 Molnar N, et al. This is an open-access article distributed under the terms of the Creative Commons Attribution License, which permits unrestricted use, distribution, and reproduction in any medium, provided the original author and source are credited. 
reduce or eliminate impacts on the surrounding World Heritage listed lagoon and coral reef [19]. Ponds are continuously irrigated in order to maintain water column oxygenation, with water that is pumped directly from the lagoon through a canal, and introduced by gravity at a rate increasing from 5 to $25 \%$ of the pond volume over the course of the rearing cycle. Excess water overflows the ponds and is discharged into the adjacent mangroves. Following the shrimp harvest, the ponds are drained and left dry for $\sim 4$ months, the "assec" period, until the subsequent production cycle [21]. Several studies have investigated the impacts of shrimp farm effluents on mangrove ecosystems, especially in mangrove creeks. Effluents have been shown to significantly increase water column chlorophyll $a$, dissolved inorganic nitrogen $\left(\mathrm{NH}_{4}{ }^{+}\right.$and $\mathrm{NO}_{\mathrm{X}}$ ) and total nitrogen and phosphorus concentrations [19-22]. In addition, they enhance primary and bacterial production $[23,24]$ and induce significant increases in biological oxygen demand, promoting water column hypoxia or anoxia $[19,25]$. However, these effects are generally localized to areas close to effluent outlets, and water quality parameters and phytoplankton biomass return to natural levels within a few months after the cessation of the discharge [19,25]. In contrast, much less is known concerning the effects of shrimp farm effluents on processes within the benthic compartment [26,27]. Within this context, our main objective was to understand the influence of the effluents release on the biogeochemistry of mangrove sediments. Due to the cyclical nature of the farming practiced in New Caledonia, a monitoring of the physico-chemical parameters of the mangrove sediment was carried out during a whole year, including the complete cycle of farming, and the "assec" period, to see if the sediment can regenerate during this period. In New Caledonia, farms are built on saltflats, and the first mangrove strata receiving effluents is generally the Avicennia stand. A densification of this stand following implantation of a shrimp farm was observed [28]. The parameters followed during this study were: i) the benthic primary production (chlorophyll biomass), ii) the physico-chemical parameters of sediments (redox potential, $\mathrm{pH}$, salinity, total organic carbon (TOC), total nitrogen (TN), total sulfur (TS), $\delta^{13} \mathrm{C}$ and $\delta^{15} \mathrm{~N}$ ), iii) and the concentrations of dissolved nitrogen, iron and phosphorus. A mangrove in the same bay and developing in the same physiographic conditions but free of any anthropogenic input was used as reference.

\section{Materials and Methods}

\section{Study site and sampling strategy}

New Caledonia (NC) is a French archipelago located in the southwestern part of the Pacific Ocean, and is characterized by the world's largest lagoon surrounding the main island. The climate of the main island is strongly influenced by the inter-tropical convergence zone (ITCZ) with mean annual rainfall close to $1100 \mathrm{~mm}$ and average monthly air temperatures fluctuating between $20^{\circ} \mathrm{C}$ and $27^{\circ} \mathrm{C}$ (Meteo France data). The west coast of the main island, where the study sites are (Figure 1), is characterized by a semi-arid tropical climate. The smallest thermal amplitude and the highest temperatures occur from December to February (i.e. in summer); and the largest thermal amplitude and the lowest temperatures occur from July to September (i.e. in winter) (Figure 2). Tropical depressions can occur during summer, which is thus also the wet season. In New Caledonia, a total of 24 mangrove species occupy $\sim 25000$ ha; $88 \%$ of mangroves are located on the west coast due to coastal morphology, but biodiversity is higher on the east coast because of less arid conditions. Along the west coast of the main island, which is characterized by a semi-arid climate, the same mangrove zonation can be observed. Rhizophora trees, representing

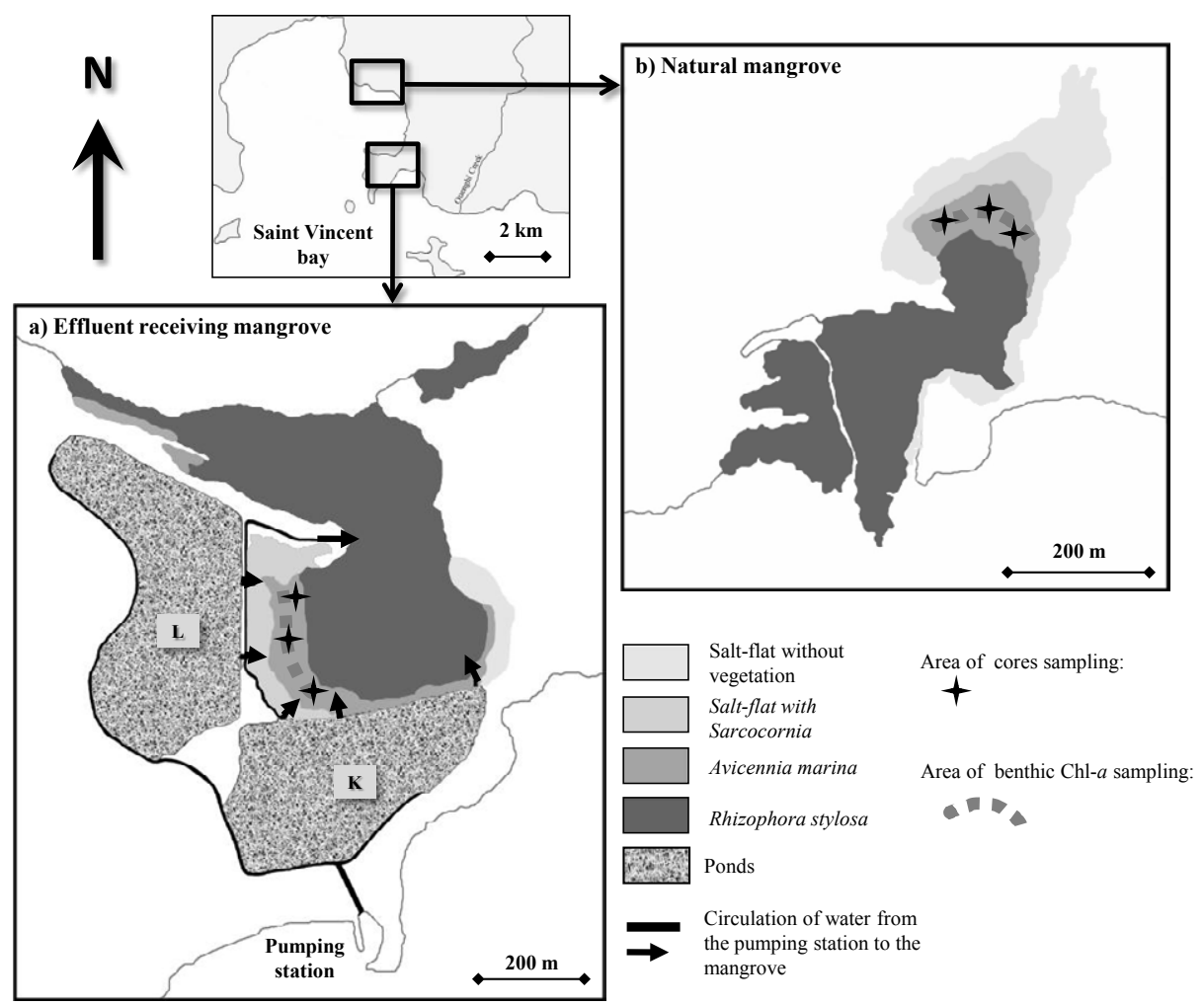

Figure 1: Map of the studied area in Saint Vincent Bay (New Caledonia), showing the position of the ponds ( $\mathrm{K}$ and $\mathrm{L}$ ), and the location of the sampling sites in the effluent receiving mangrove (a) and in the control mangrove (b). 

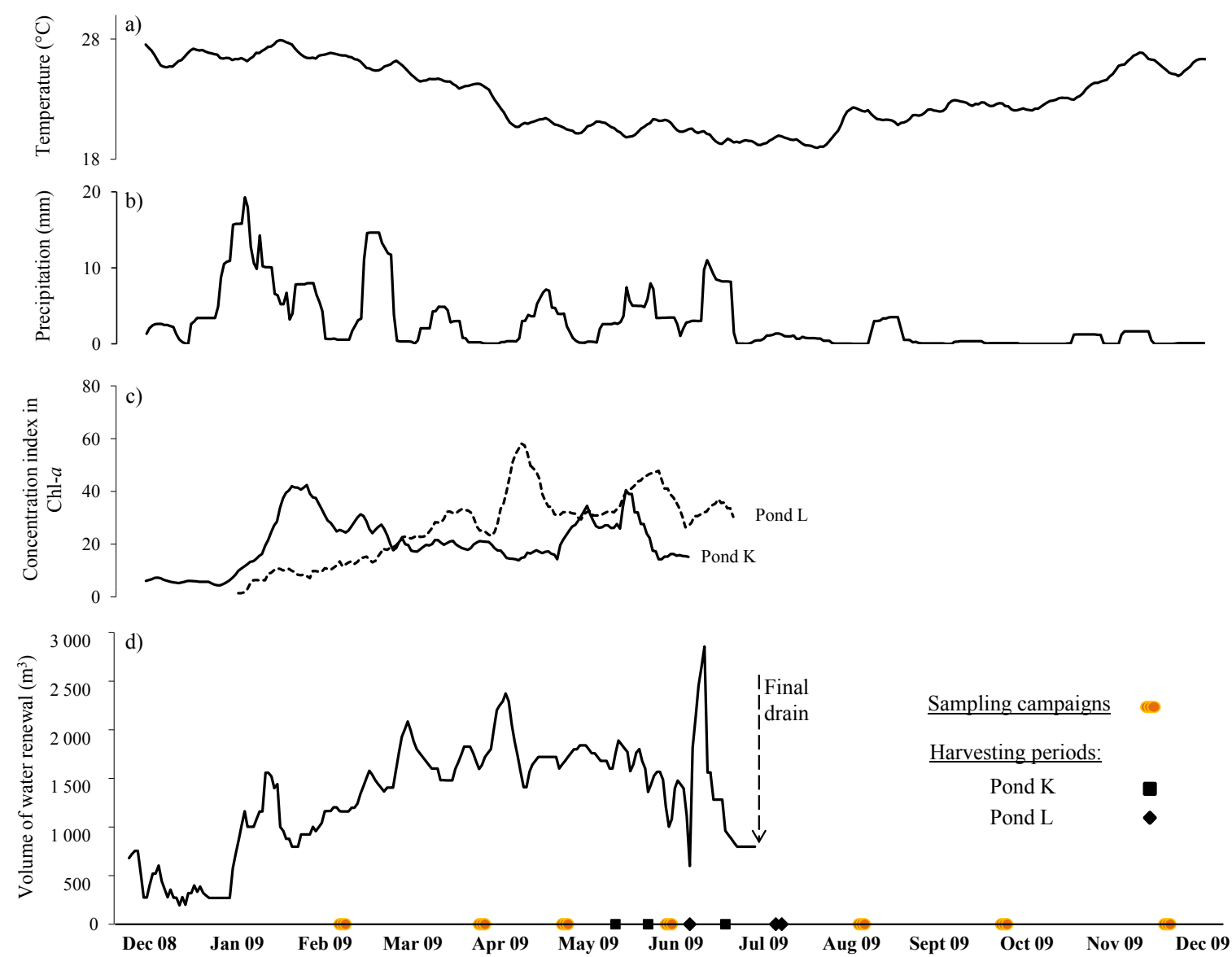

Figure 2: Temperature (a) and precipitation (b) measured at the closest Météo-France station (averaged over 10 days), concentration index in $\mathrm{Chl}$-a measured in the ponds water (pond $\mathrm{K}$ and $\mathrm{L})(\mathrm{c})$, and total volume of water renewal by day for the two ponds $(\mathrm{L}+\mathrm{K})$. Harvesting periods of the shrimp farm and sampling campaigns are specified.

$55 \%$ of the total mangrove areas in New Caledonia, develop mainly in zones swept daily by tides, while Avicennia trees, representing $14 \%$ of the total mangrove areas, develop at higher elevations, at the borders of the salt-flat, which occupies the higher area in the intertidal zone. The effluent receiving mangrove and the control mangrove are located on the west coast of New Caledonia in the northern part of the same bay, Bay of Saint Vincent, and present the same zonation (Figure 1). None of the studied mangroves are crossed by a river; they are thus mainly subject to the marine influence, without significant freshwater input except by runoff during rainfall. The control mangrove $\left(21^{\circ} 54^{\prime} \mathrm{S}\right.$, $166^{\circ} 04^{\prime} \mathrm{E}$ ) covered 20 ha (Figure 1a) and was free of significant anthropogenic influences. The effluent receiving mangrove $\left(21^{\circ} 56^{\prime} \mathrm{S}\right.$, $166^{\circ} 04^{\prime} \mathrm{E}$; total area of 28.9 ha (Figure $1 \mathrm{~b}$ ), located $2 \mathrm{~km}$ from the control mangrove) receives effluent discharges from the "Ferme Aquacole de la Ouenghi" shrimp farm (FAO). Visual density and size distributions of the mangrove trees differed between the two studied mangroves. In the control mangrove, the Avicennia trees were sparsely distributed, bush-like and never exceeded $1 \mathrm{~m}$ in height. In contrast, in the mangrove receiving shrimp farm effluents, there was a higher density of trees. Pictures of the effluent receiving mangrove before the farm constructions show that the density was the same than in the control one. The FAO shrimp farm exploitation started in 1989 and operates two $1 \mathrm{~m}$ deep rearing ponds of $10.5(\mathrm{~L})$ and $7.5(\mathrm{~K})$ ha, respectively, which are constructed within and have replaced the original salt-flat.
Like the majority of shrimp farms in New Caledonia, FAO operates a semi-intensive rearing system. Ponds are stocked with the blue shrimp, Litopenaeus stylirostris, at a density of $\sim 17$ individuals. $\mathrm{m}^{-2}$ in December/ January, which are reared for $\sim 8$ months (Figure 2 ). The shrimp are fed with locally produced feed pellets (35-40\% protein, SICA, New Caledonia), which are added daily throughout the rearing period, with inputs increasing from $\sim 0.25$ to $\sim 3.5 \mathrm{~kg} \cdot \mathrm{ha}^{-1} . \mathrm{d}^{-1}$ over the rearing cycle as the shrimps grow (Farm manager, Pers. Comm.). The volume of water discharged into the mangrove corresponds to the volume of the water renewed daily, and increases progressively with the growth of postlarvae and adult organisms. Effluent discharges are massive, especially during harvesting periods and during the final drain. However, not being renewed before the final drain, the volume of water released in the mangrove does not correspond to the curve of water renewal (Figure 2). The ponds were drained on 17 and 28 July 2009 respectively for ponds $\mathrm{L}$ and $\mathrm{K}$, which corresponds to the last shrimp harvest and to the maximum water discharge to the mangrove. In both mangroves (control and effluent receiving), 8 sampling campaigns were conducted from February 2009 to February 2010 in the Avicennia stands. Sampling campaigns were conducted to cover the entire production cycle of the farm with four campaigns during the rearing period, and 4 campaigns during the "assec" period. Surface sediment samples were collected to determine their benthic Chl-a contents. Five subareas were defined for each Avicennia stand, and four replicates were collected 
in each subarea. Each replicate corresponded to the pooling of five $1 \mathrm{~cm}$ depth $\mathrm{x} 2 \mathrm{~cm} \varnothing$ syringes contents. The samples were then frozen at $-20^{\circ} \mathrm{C}$ before being lyophilized for analysis. In addition, sediment cores (50 cm deep) were collected in triplicate during low tide using an Eijkelkamp gouge auger in each mangrove stand. Core locations were chosen close to the vegetation but being carefully to avoid the presence of main roots in samples. After being collected, cores were wrapped in plastic film and aluminium foil, and were transported to the airconditioned laboratory within $10 \mathrm{~min}$. Samples were collected every 5 $\mathrm{cm}$ from 0 to $50 \mathrm{~cm}$ depth. Samples were taken and frozen until they were lyophilized for analysis of Total Organic Carbon (TOC), Total Sulphur (TS), Total Nitrogen (TN), as well as for nitrogen and carbon stable isotopes. Pore-waters were extracted from $5 \mathrm{~cm}$ long sediment section with soil moisture samplers Rhizon $[29,26]$. All samples were filtered through $45 \mu \mathrm{m}$ cellulose acetate syringe-filter. An aliquot of filtered pore-water was acidified with $\mathrm{HNO}_{3}$ to prevent precipitation of reduced dissolved iron and store refrigerated for $\mathrm{Fe}$ analysis $\left(\mathrm{Fe}^{2+}\right.$ and $\left.\mathrm{Fe}^{3+}\right)$. A second aliquot was frozen at $-25^{\circ} \mathrm{C}$ for nutrient analysis $\left(\mathrm{NH}_{4}^{+}\right.$, $\mathrm{NO}_{\mathrm{X}}$, DON, DIP, DOP).

\section{Analytical methods}

Chlorophyll a analysis: Chl-a was extracted from freeze-dried sediments by using a methanol $93 \%$ solution and their concentrations determined fluorometrically [30]. Fluorometer used was a Turner Designs TD700 equipped with an optical kit $n^{\circ} 7000-961$ including an excitation filter of 340-500 $\mathrm{nm}$ wavelength, and an emission filter up to $665 \mathrm{~nm}$ wavelength. Pigments in methanol were then excited in the fluorometer with a $450 \mathrm{~nm}$ wavelength beam of light and fluorescence emitted at $664 \mathrm{~nm}$. Chl-a data are represented in a Boxplot (realized with R). They were, first, analyzed by a non-parametric KruskallWallis test, and then by a Wilcoxon test to compare mean values for pairs (control mangrove vs. effluent receiving mangrove, between campaigns), a Benjamini and Hochberg correction were used.

Salinity, $\mathrm{pH}$, redox potential and $\mathrm{\Sigma H}_{2} \mathrm{~S}$ measurements: Physicochemical parameters were determined in an air-conditioned laboratory within $30 \mathrm{~min}$ after the core sampling. Salinity, $\mathrm{pH}$, redox and $\mathrm{\Sigma}_{2} \mathrm{~S}$ were measured like previously described [26]. pH was measured with a WTW pH meter electrode. Salinity was determined with an Atago refractometer. We used a WTW sulphide ion specific electrode allowing, with the appropriate calculations (taking into account $\mathrm{pH}$ and salinity), the determination of the total sulphide concentration (TS, $\mathrm{S}^{2-}, \mathrm{H}_{2} \mathrm{~S}$ and $\mathrm{HS}^{-}$) [31] based on the calibration of the electrode by titration, as previously described $\left(\log \left(\mathrm{S}^{2-}\right)=-0.024^{\star} \mathrm{E}(\mathrm{V})-0.878\right)$ [32] The redox potential was measured with a combined $\mathrm{Pt}$ and $\mathrm{Ag} / \mathrm{Ag} /$ $\mathrm{Cl}$ reference electrode connected to a WTW $\mathrm{pH} / \mathrm{mV} / \mathrm{T}$ meter. Redox data are reported relative to a standard hydrogen electrode after adding $202 \mathrm{mV}$ to the original $\mathrm{mV}$ values obtained with an $\mathrm{Ag} / \mathrm{AgCl}$ reference electrode at $25^{\circ} \mathrm{C}$. The following redox scale was used:

- oxic $>400 \mathrm{mV}$, contain measurable dissolved oxygen,

- $100 \mathrm{mV}>$ Suboxic $>400 \mathrm{mV}$, lack measurable oxygen or sulphide but contain dissolved iron or manganese, and no reduction of sulfate.

\section{- Anoxic $<100 \mathrm{mV}$, sulfato reduction.}

Pore-water analysis: Dissolved iron $\left(\mathrm{Fe}^{2+}\right.$ and $\left.\mathrm{Fe}^{3+}\right)$ were measured in pore-waters by colorimetric procedures with a precision of $\pm 5 \%$ [33]. Sulphate was analysed according to a nephelometric method with a precision of about $5 \%$ [34]. $\mathrm{NH}_{4}{ }^{+}$concentrations were determined by the fluorimetric method [35] using a TurnerDesigns TD700 fluorimeter. $\mathrm{NO}_{\mathrm{X}}$ (nitrate+nitrite) concentrations were determined using an
Autoanalyzer III (Bran+Luebbe) [36]. Total Dissolved Nitrogen (TDN) concentrations were determined as $\mathrm{NO}_{\mathrm{x}}$ following oxidation. Dissolved Organic Nitrogen (DON) concentrations were calculated by difference between the TDN and the measured inorganic forms $\left(\mathrm{NH}_{4}{ }^{+}\right.$ and $\mathrm{NO}_{\mathrm{x}}$ ). Dissolved Inorganic Phosphorus (DIP) concentrations were determined using the autoanalyzer III (Bran+Luebbe) [37]. Dissolved Organic Phosphorus (DOP) was determined by difference of the TDP pool minus DIP pool.

Sediment solid phase analysis: Sediment samples were analyzed only once at the beginning of the study to compare the sediment characteristic of the two Avicennia stands.

Total organic carbon (TOC) was determined using a RockEval 6 pyrolisis $[38,39]$. Total nitrogen (TN) and total sulphur (TS) concentrations were measured by combustion at $1100^{\circ} \mathrm{C}$ with a CNS-2000 LECO apparatus. Prior to analysis for the determination of $\delta^{13} \mathrm{C}$ and $\delta^{15} \mathrm{~N}, 20 \pm 1 \mathrm{mg}$ from each sample were freeze-dried and grounded. Surface sediments were treated with the addition of $1 \mathrm{~N}$ $\mathrm{HCl}$ solution to remove carbonates. The isotopic ratio (R) values of dried samples $\left({ }^{13} \mathrm{C} /{ }^{12} \mathrm{C}\right.$ or $\left.{ }^{15} \mathrm{~N} /{ }^{14} \mathrm{~N}\right)$ were determined at the UC Davis Stable Isotope Facility (Department of Plant Sciences, University of California at Davis, Davis, California) using a Europe Hydra 20/20 mass spectrometer equipped with a continuous flow IRM device and are reported in standard delta notation $\left(\delta^{13} \mathrm{C}\right.$ or $\left.\delta^{15} \mathrm{~N}\right)$, defined as parts per thousand (\%o) deviation from a standard (Vienna Peedee belemnite for $\mathrm{C}$ and atmospheric $\mathrm{N}_{2}$ for $\mathrm{N}$ ). The analytical precision (standard deviation for repeated measurements of the internal standards) for the measurement was $0.06 \%$ and $0.13 \%$ for $\delta^{13} \mathrm{C}$ and $\delta^{15} \mathrm{~N}$, respectively.

\section{Results and Discussion}

\section{Mangrove zonation and solid phase characteristics of man- grove sediments}

In New Caledonia, shrimp pounds are built upstream of the mangrove forests within the salt-flat areas. Water is pumped in daily from the nearby lagoon for a partial renewal of the pond water that maintains salinity at $32-39 \%$ and dissolved oxygen above $3.5 \mathrm{mg} . \mathrm{L}^{-1}$. It flows through the intake canal while the excess pond water drains from the opposite end of the pond into the adjacent mangroves, mainly the Avicennia stand. Along the west coast of the main island, which is characterized by a semi-arid climate, the same mangrove zonation can be observed. Rhizophora trees, representing 55\% of the total mangrove areas in New Caledonia [40], develop mainly in zones swept daily by tides, while Avicennia trees, representing $14 \%$ of the total mangrove areas, develop at higher elevations, at the borders of the salt-flat, which occupies the higher area in the intertidal zone. This topographic zonation induces differences in the length of immersion by tides, which is translated by the water content of the sediment. In a previous study [41], we suggested that surface ground elevation indirectly controlled zonation, by controlling the length of immersion, the amount of evaporation, and thus the salinity of pore-water; the latter being recognized as a key factor in mangrove zonation [42,43]. Within the Avicennia stand, the total effluent release by the shrimp farm over a rearing cycle was approximately $2.5810^{9} \mathrm{~L}$ (pers. com. farm manager), with total $\mathrm{N}$ and $\mathrm{P}$ loads being $\sim 2.3$ and $\sim 0.5$ tons, respectively [44]. These values were equivalent to loads of $\sim 79 \mathrm{~kg} \mathrm{~N}$ $\mathrm{ha}^{-1}$ and $\sim 19 \mathrm{~kg} \mathrm{P} \mathrm{ha}^{-1}$, which are about the maximum quantities of $\mathrm{N}$ and $\mathrm{P}$ that can be processed and immobilized by a mangrove ecosystem [45]. Elevated nutrient concentrations were measured in an external marine creek of the effluent receiving mangrove, suggesting that mangrove was only a partial filter for the nutrient loads [44]. However, 
higher density and much greater individual size of the mangrove trees in the effluent receiving mangrove compared to the adjacent control mangrove, suggest that a proportion of the nutrient loads had been assimilated into the mangrove biomass over the 20 years of operation of the studied shrimp farm. Concerning surface sediments, the quality and the quantity of the organic matter seemed to strongly differ between the two mangroves. POC and $\delta^{15} \mathrm{~N}$ were higher in the effluent receiving mangrove, while $\mathrm{C} / \mathrm{N}$ values were lower, indicating a greater algae development at sediment surface compared to the control mangrove (Figure 3). In fact, the excess nutrients exported from shrimp ponds were predominantly in particulate organic forms [44], which may have induced a higher benthic primary productivity (see next chapter on Chl-a seasonal evolution). Surprisingly, within the sedimentary column, our results indicate that the effluent receiving mangrove was not enriched in organic matter compared to the control mangrove, with TOC values ranging between 2 and 5\% in the upper $20 \mathrm{~cm}$ of the two mangroves (Figure 3). This organic enrichment can be considered as moderated compared to other mangrove swamps $[46,47]$. This result may be linked to the root system of Avicennia trees, which is mainly a radial cable root system that develops close to sediment surface and that is less developed than for other species like Rhizophora [32]. It can also result from intense decay processes of the Organic Matter (OM) developing in the effluent receiving mangrove (see next chapter on pore-water physico-chemical properties). At depth, a TOC increase, with values reaching more than $8 \%$ at $40 \mathrm{~cm}$ depth (Figure 3), resulted from an increased proportion of red tissues characteristics of Rhizophora wood, visually observed in the core. This observation was made in other mangroves developing on the west coast of New Caledonia [26,41], implying that the Avicennia forests develop on sediments that were previously colonized by Rhizophora trees. This TOC increase is correlated with an increase in $\mathrm{C} / \mathrm{N}$, from 15 in the upper cores to 50 at depth, and a decrease in $\delta^{13} \mathrm{C}$ from -22 to $-26 \%$ (Figure 3), confirming an increase proportion of higher plant debris in the sedimentary organic pool. All the latter parameters presented the same depth trend in both mangroves. However, the upper sediment of the effluent receiving mangrove was characterized by significantly higher $\delta^{15} \mathrm{~N}$ values compared to the control mangrove (WMW Test, $p<0.05$ ) (Figure 3). $\delta^{15} \mathrm{~N}$ signatures of the different sources of OM were: $+4.0 \pm 1.7 \%$ o for Avicennia tissues, $+2.4 \pm 2 \%$ for Rhizophora tissues, $+1.1 \pm 1.7 \%$ o for effluents, $+2.4 \pm 1.9 \%$ for cyanophycae,+1.3 $\pm 1.6 \%$ for diatoms. Since N benthic processes, e.g. nitrification and denitrification, usually leads to ${ }^{15} \mathrm{~N}$ enrichment, our results are rather related to a different composition of the sedimentary organic pool. The sediment of the control mangrove presented a typical signature of a blend between microphytobenthos and higher plant debris, with $\delta^{15} \mathrm{~N}$ values ranging between +2 and $+3 \%$, while the contribution Avicennia trees in the sedimentary organic pool seemed to be higher in the effluent receiving mangrove, with $\delta^{15} \mathrm{~N}$ values ranging between $+5 \%$ at the top of the core and $+2 \%$ at depth. Although elevated algae development at sediment surface, the increased proportion of Avicennia detritus in the sedimentary organic pool highlighted that a large quantity of effluents released in the mangrove had been assimilated into mangrove trees biomass.

\section{Influence of shrimp farm effluents on the natural seasonal dynamic of microphytobenthos}

Contribution of microphytobenthos to mangrove primary productivity is usually low due to light limitation induced by close canopy, low nutrient input, and growth inhibition resulting from the high tannin content of mangrove litter [48]. Consequently, Chl-a concentrations at sediment surface rarely exceed $5 \mu \mathrm{g} \cdot \mathrm{g}^{-1}$ [49]. Nevertheless, with an open canopy and high nutrient input, microphytobenthos can contribute to a high percentage of the sedimentary organic matter [50]. The Chl-a concentrations measured in the control mangrove ranged between $6.9 \pm 2.0$ and $12.7 \pm 7.1 \mu \mathrm{g} . \mathrm{g}^{-1}$ (Figure 4), which represent relatively high concentrations for mangrove

\section{AVICENNIA}

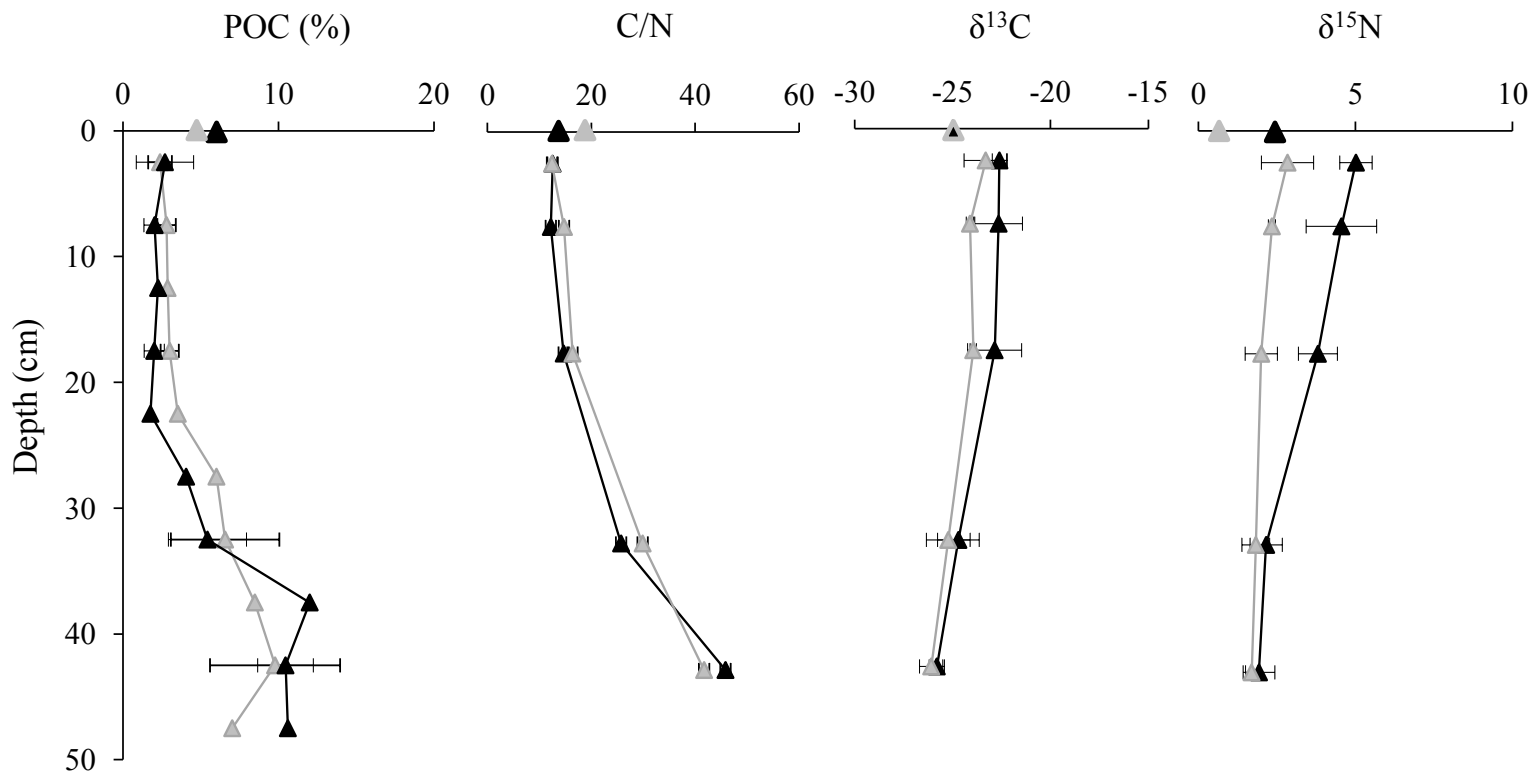

Figure 3: POC content, $\mathrm{C} / \mathrm{N}, \delta^{13} \mathrm{C}$ and $\delta^{15} \mathrm{~N}$ distribution with depth within the Avicennia sediment in the effluent receiving mangrove (black line) and in the control mangrove (gray line). 
sediments. Due to the semi arid conditions prevailing on the west coast of New Caledonia, and their position in the tidal range, $A$. marina trees are dwarf ( $\sim \mathrm{m}$ in height) and thus Avicennia stands are characterized by open canopy, meaning that solar radiation can reach sediment surface, which may explain the high chlorophyll-a content measured. These results are consistent with other studies concerning mangroves developing in the same climatic and physiographic conditions [51]. The Chl-a concentrations measured in the effluent receiving mangrove were significantly higher than in the control one (Wilcoxon Test, $p<0.01$ ), ranging from $17.7 \pm 7.3$ to $38.6 \pm 27.5 \mu \mathrm{g} . \mathrm{g}^{-1}$ along the year (Figure 4). The impact of shrimp farm effluents on phytoplankton productivity in mangrove was already evidenced in creeks $[19,23]$, but rarely on the microphytobenthos productivity [24]. Our results translate a high primary productivity at sediment surface as a result of nutrients input from the shrimp ponds. The high Chl-a concentrations measured may also result from the deposit of the phytoplankton-rich effluents. However, this algal mat was not homogenous as translated by the high standard deviations of the Chl-a measurements. The latter may be explained by the high heterogeneities of mangrove canopy closure and pneumatophore density compared to the control mangrove, as well as a higher crab density, which can induce different grazing and bioturbation [52]. Higher concentration in Pheo- $a$, representing the degradation products of Chl-a, were also measured in the effluent receiving mangrove $\left(23.4 \pm 3.8\right.$ to $\left.28.8 \pm 5.8 \mu \mathrm{g} . \mathrm{g}^{-1}\right)$ compare to the control one $\left(5.2 \pm 1.2\right.$ to $\left.6.7 \pm 1.9 \mu \mathrm{g}^{-\mathrm{g}^{-1}}\right)$. This result may indicate efficient decomposition processes at sediment surface. From February to August, period that corresponds to a temperature decrease, Chl-a concentrations were quite stable in the control mangrove (Wilcoxon Test, $p>0.05$ ), while they increased from October to February, when the temperature increased from $22.4 \pm 1.4^{\circ} \mathrm{C}$ to $27.8 \pm 1.1^{\circ} \mathrm{C}$ (Figure 2 ). Seasonal evolution of the microphytobenthos productivity was already evidenced in New Caledonia [53]. These authors observed biomass and productivity increases of micro and macro-algae with increase of temperature and irradiance during summer. The quantity of primary producers (chl-a biomass) at sediment surface increases with temperature, solar radiation, but also with soil water content, which depends both on the season and the position in the tidal zone [51]. In New Caledonia, the summer (from December to February) is characterized by high temperature but also intense rainfall, which can represent ideal conditions for the growth of microphytobenthos. The seasonal evolution of the Chl-a concentrations in the effluent receiving mangrove was similar to the one in the control mangrove, with higher values in summer. From February to June, when the farm was active, concentrations ranged between $17.7 \pm 13.9 \mu \mathrm{g} . \mathrm{g}^{-1}$ and $25.7 \pm 13.9 \mu \mathrm{g} . \mathrm{g}^{-1}$ (Figure 4), without any significant differences during the 4 sampling campaigns (Wilcoxon Test, $p>0.05$ ). In August after the final drain, the concentrations increased, reaching $30.0 \pm 14.6 \mu \mathrm{g} . \mathrm{g}^{-1}$. Thus the release of high quantity of enriched water in the mangrove induced a high microphytobenthos development, even during the winter period. During the non active period of the farm, from August to February, the Chl-a concentrations did not decrease, with a mean value of $27.8 \pm$ $11.3 \mu \mathrm{g} . \mathrm{g}^{-1}$ (Figure 4). This result is opposite to what was observed for mangrove creeks, where phytoplankton biomass returned to natural levels within a few months after the cessation of the discharge $[19,25]$.

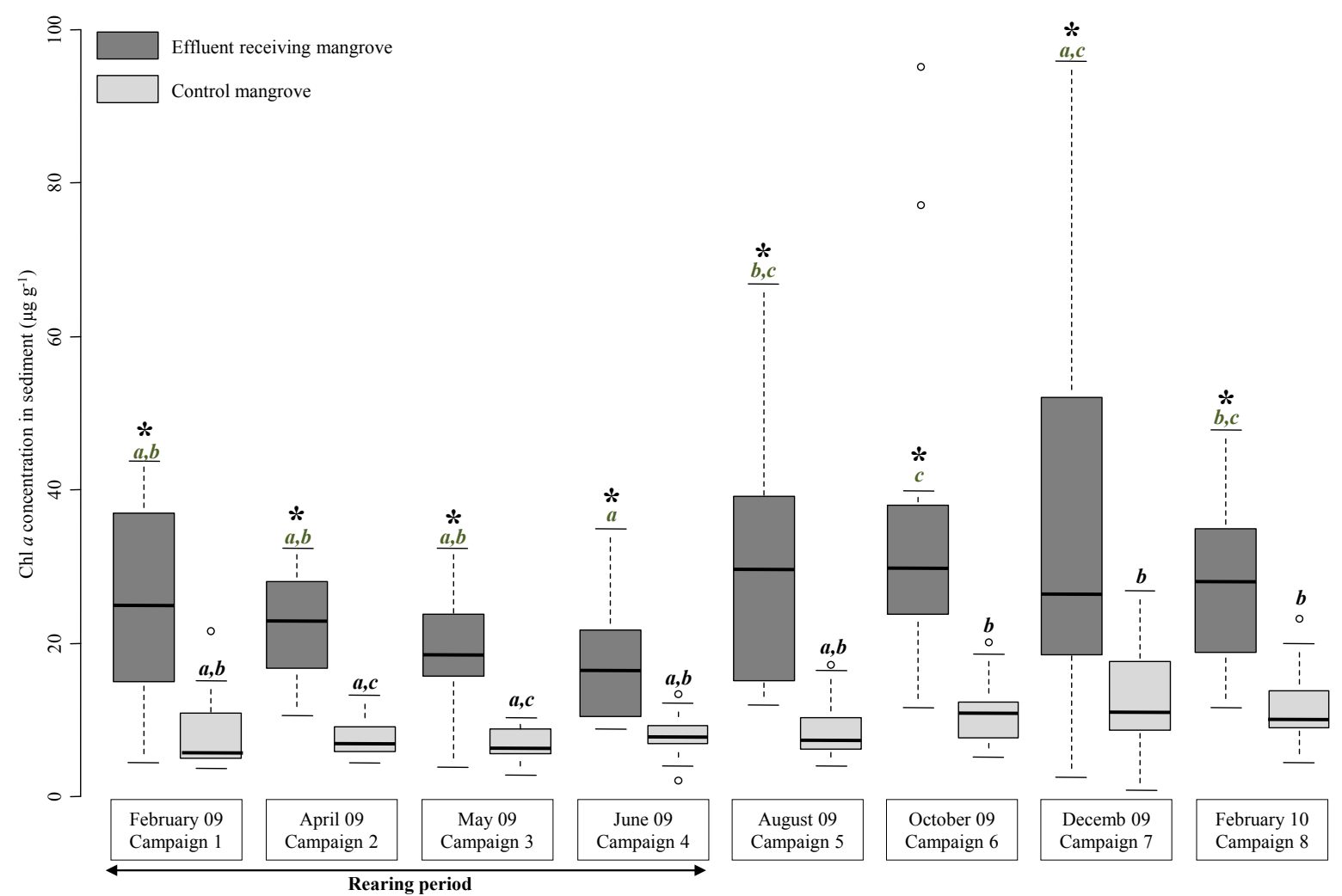

Figure 4: Boxplot representation of benthic Chl-a concentration ( $\mu \mathrm{g} \cdot \mathrm{g}^{-1}$ of sediment) measured at sediment surface in the effluent receiving mangrove (dark grey) and in the control mangrove (light grey) during 8 campaigns between February 2009 and February 2010 . Significant result of comparison of means test (WMW, $p<0.05$ ) between the two mangroves for each track is marked by a star. Significant differences test (WMW, $\mathrm{p}<0.05$ ) between sampling periods for each mangroves are indicated by different letters. 
Citation: Molnar N, Marchand C, Deborde J, Della Patrona L, Meziane T (2014) Seasonal Pattern of the Biogeochemical Properties of Mangrove Sediments receiving Shrimp Farm Effluents (New Caledonia). J Aquac Res Development 5: 262. doi:10.4172/2155-9546.1000262

Page 7 of 13

Effluent release in the mangrove occurred during winter, when the metabolism of benthic organism are at their minimum [53,54], and the final drain occurred just before the seasonal temperature increase, period during which the microphytobenthos biomass increased in the control mangrove. Thus, in the same way that the effluents feed the trophic dynamic of the water column [24], they contribute to an increased development of micro-algae and bacteria, as already shown in mangrove sediments exposed to effluents from agricultural activities [55]. These results highlight that the Chl-a concentrations at mangrove sediment surface, and thus the microphytobenthos activity, were driven both by the release of effluents and the climatic seasonal evolution. The fact that the final drain occurred just before the temperature increase induced a boosted algal bloom, and the fact surface sediments never recovered its natural characteristics.

\section{Influence of shrimp farm effluents on mangrove pore-water properties}

Natural seasonal evolution of mangrove pore-waters: Within the control mangrove, pore-water salinity varied along the year and with depth. In the upper cores, salinity increased from less than 40 in February to 65 in October, while below $35 \mathrm{~cm}$ depth, values were quite stable along the year, around 65 (Figure 5). Surface salinities may vary responding to physical factors (evaporation, intensity of rain, tidal flooding and position in the mangrove) and biological factors (transpiration). In fact, salinity values increased from the hot and wet season to the cool season, which is characterized by low rainfall in New Caledonia. During this season, surface salinity was almost twice that of seawater, highlighting the influence of evaporation processes, as observed in Australia [56]. In addition, plant transpiration may increase pore-water salinity in mangrove sediments. In a previous study, an increase of pore-water salinity with Avicennia trees development was observed [32]. The high and stable basal salinities measured along the year cannot be explained by evapo-transpiration processes since Avicennia trees produce horizontal cable roots just below the sediment surface (in the upper $30 \mathrm{~cm}$ ). Flow of underground water may explain this phenomenon, either by advection of salt water beneath fresh or less saline water, or vertical migration of water through crab holes [57], or via convection processes $[32,58,59]$. Redox conditions also varied along the year and with depth. During the whole year, the upper cores were characterized by Eh values ranging between 100 and $200 \mathrm{mV}$, slightly acidic $\mathrm{pH}$ (Figure 5), and the presence of $\mathrm{Fe}^{2+}$ and $\mathrm{Fe}^{3+}$ (Figure 6), indicating oxic to suboxic conditions. At depth, Eh values were lower than $0 \mathrm{mV}$, dissolved iron was under the detection limit, evidencing anoxic processes, as observed in other mangroves [60-62]. Within the upper sediment, suboxic to oxic conditions may be explained first by bioturbation. Crab burrows, or holes created by decomposing roots, may allow the renewal of electron acceptors during high tide [63]. Additionally, the root system of Avicennia trees has the capacity
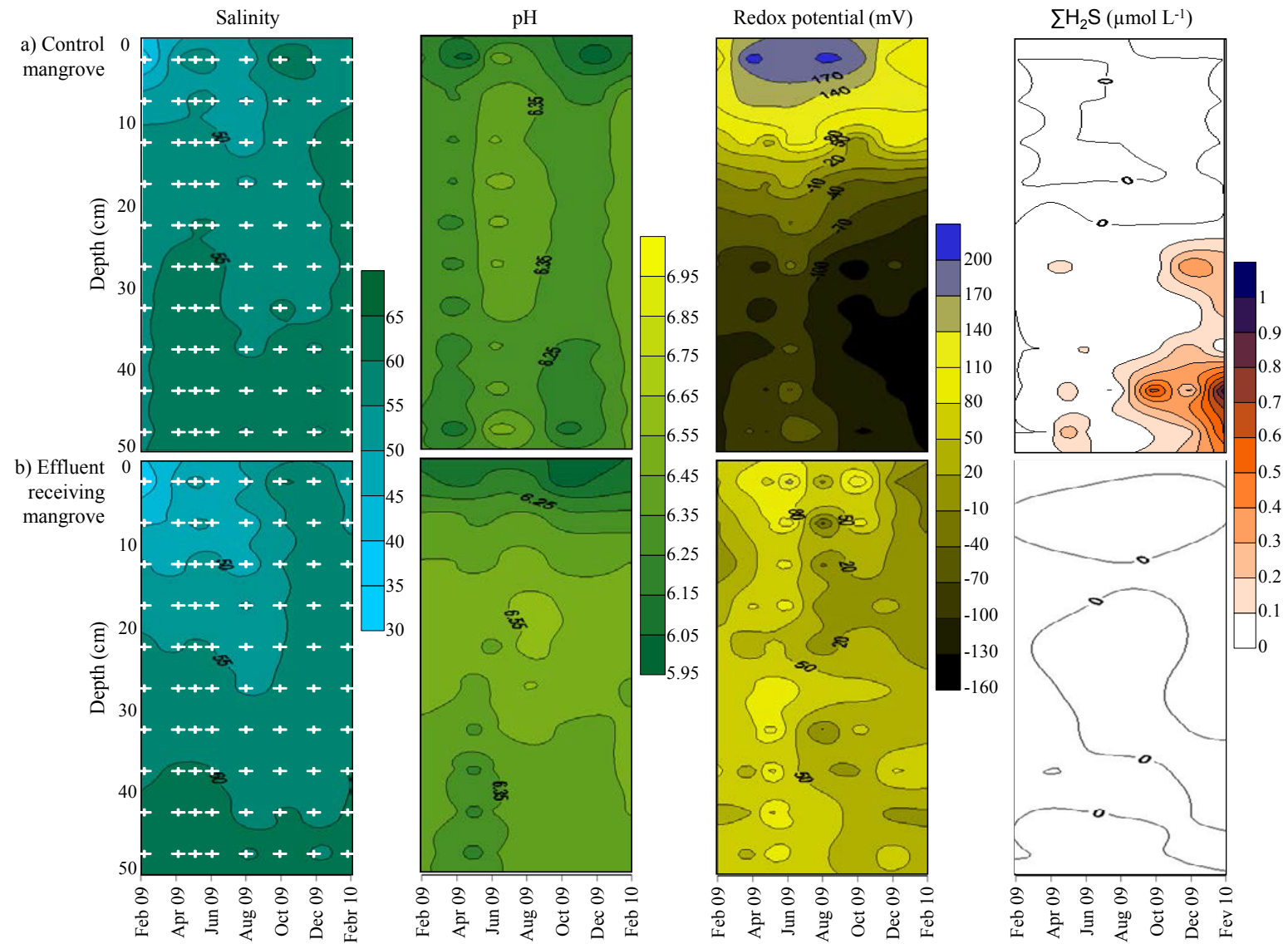

Figure 5: Temporal evolution of pore-water parameters: salinity, $\mathrm{pH}$, redox potential, and total free dissolved sulfur $\left(\mathrm{SH}_{2} \mathrm{~S}\right)$ (means of tree replicates), in the control mangrove (a) and effluent receiving mangrove (b). Graphical representation was performed under Surfer 8 , with Krigging interpolation method for extrapolating values between sampling periods. Measurement points are represented by crosses visible on the graphs of salinity (averaged on 3 replicates). 
to diffuse oxygen into the sediment, and to create large oxidized rhizospheres [64-68]. In French Guiana, we demonstrated that the older the Avicennia forest, the higher the redox values, providing the sedimentary organic content was low, highlighting the key role of root growth on redox conditions [69]. Mangrove plant species distribution is correlated with soil redox potential and sulphide concentration, and reciprocal effects exist between soil characteristics and tree roots, with a negative correlation between pneumatophore density and sulphide concentrations [43]. Clark et al. [65] attributed the "lower oxidation zone" of their redox stratification model to the activity of the radial cable roots of Avicennia; while the "upper oxidation zone" was attributed to animal bioturbation. The two zones can merge in case of developed root system, resulting in suboxic to oxic conditions in the upper $30 \mathrm{~cm}$ of the sedimentary column. In this layer, increasing oxygen concentration is expected to favour the biodegradation of organic material and/or the oxidation of Fe sulfides, causing the observed $\mathrm{pH}$ decrease. At depth, the sedimentary organic content was higher as a result of the decomposing Rhizophora roots, explaining the anoxic conditions prevailing during the whole year. Sulphate reduction led to sulphide precipitation in this zone, explaining the total solid sulphur content reaching more than 6\% (Figure 6). As soon as sulphate-reduction began, dissolved Fe concentrations decreased (Figure 6). reflecting the co-precipitation of $\mathrm{Fe}$ and $\mathrm{S}$ in the form of framboidal pyrite (optically observed in a previous study [61]). Fe(III)-bearing goethite and phyllosilicates were the major Fe hosts in the upward horizons of mangroves in Northern New Caledonia [70]. These mineral species progressively disappear with increasing depth where $\mathrm{Fe}(\mathrm{II})$-bearing pyrite forms in the hydromorphic mangrove layers. Sediment was thus redox stratified whatever the season. Concerning the seasonal evolution of the redox conditions, Eh values were higher on the whole sedimentary column from April to August than from October to February, the hottest months (Wilcoxon Test, $p<0.05$ ) (Figure 5). In addition, the presence of dissolved sulphides $\left(\mathrm{SH}_{2} \mathrm{~S}\right)$ was evidenced at depth only from October to February (Figure 6). The temperature dependence of soil organic matter decomposition is still under debate, but may explained this trend [71]. In addition, the activity of decomposers, like fungi present even in anoxic and sulfidic sediments [72], may increase under these conditions. Eventually, summer was characterized by an increase of phytobenthos productivity as well as mangrove trees productivity [73], which may have induced a greater input of $\mathrm{OM}$ to the sediment, greater oxygen consumption and thus lower Eh values in the upper core. Concerning nitrogen species, DON concentrations ranged from 30 to $150 \mu \mathrm{mol} . \mathrm{L}^{-1}$ along the year (Figure 7 ). In a more developed mangrove forest in Malaysia, DON concentrations ranged from 79 to $315 \mu \mathrm{mol} . \mathrm{L}^{-1}$ [60]. Mangrove ecosystems are characterized by a high net primary productivity (NPP), and high rate of organic accumulation in their soils $[47,74]$, which may lead to high DON concentrations in pore-waters. The fact that the highest concentrations were measured at the root level, and during the hottest month, may evidence the role of the production of root exudates in the enrichment of mangrove soil in DON. The concentrations of $\mathrm{NH}_{4}^{+}$and $\mathrm{NO}_{\mathrm{X}}$ were very low (Figure 7). $\mathrm{NH}_{4}^{+}$concentrations ranged between 1 and 4 $\mu$ mol.L $\mathrm{L}^{-1}$ between 10 and $25 \mathrm{~cm}$ depth, the latter depth corresponding to the maximum densities of Avicennia roots [75]. $\mathrm{NO}_{\mathrm{X}}$ concentrations mainly ranged between 1 and $2 \mu \mathrm{mol} . \mathrm{L}^{-1}$ during winter, and were under the detection limit during the hottest months, December and February. High consumption of $\mathrm{NH}_{4}^{+}$by mangroves trees for their growth may explain these low concentrations [76,77]. In addition, ammonium is usually extremely rapidly recycled in pore waters (a few hours to two days) [77]. In presence of oxygen, nitrification can occur, producing nitrates that can be used by mangrove plants or subjected to denitrification processes. The fact that nitrates were under the detection limit during the hottest months may suggest that denitrification can be very efficient. In a previous study, we demonstrated that pristine mangrove sediments may be a net sink for inorganic nitrogen [44]. Dissolved organic phosphorus concentrations ranged between 1 and $5 \mu \mathrm{mol} . \mathrm{L}^{-1}$ from February to August, and were lower than 1 $\mu$ mol. $L^{-1}$ from October to February (Figure 8). In the upper $20 \mathrm{~cm}$, the concentrations of DIP were almost negligible during the whole year. This superficial layer corresponds to the root zone of Avicennia and densest microalgae populations. DIP is a limiting nutrient and fuels the growth of mangroves. Moreover, as reduced iron was present in pore-waters of this layer, oxygen diffusion from Avicennia roots could induce the formation of a reactive oxide iron zone [70]. The presence of iron hydroxides and oxihydroxides, which have a strong adsorption capacity for P could constitute a huge trap of DIP [78]. They can rapidly stored DIP from the pore-waters and perhaps from the water column. Under the root layer, concentrations of DIP increased and ranged between 1 and $10 \mu \mathrm{mol} . \mathrm{L}^{-1}$, especially during the hottest month. Anoxic conditions induced iron oxide dissolution, which release DIP into the

\section{Winter}

\section{Summer}
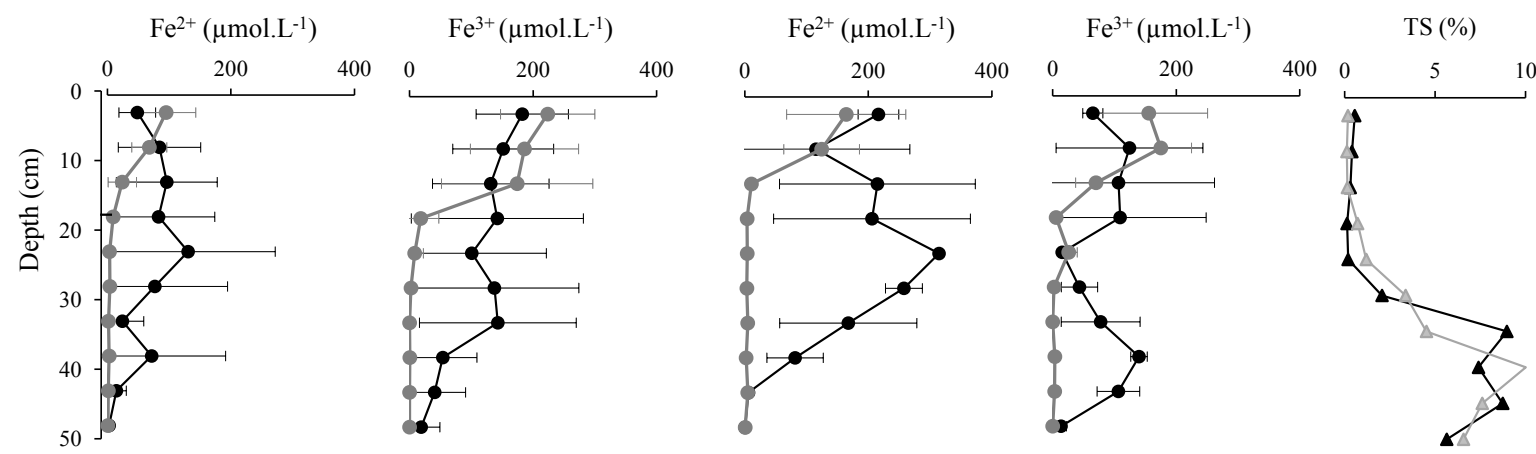

Figure 6: Dissolved iron ( $\mathrm{Fe}^{2+}$ and $\mathrm{Fe}^{3+}$ ) and total solid sulphur (TS) in Avicennia sediments measured in June (winter) and in December (summer) 2009 in the effluent receiving mangrove (black line) and in the natural mangrove (gray line) (means of tree replicates $\pm \sigma$ ). TS were only measured in June. 


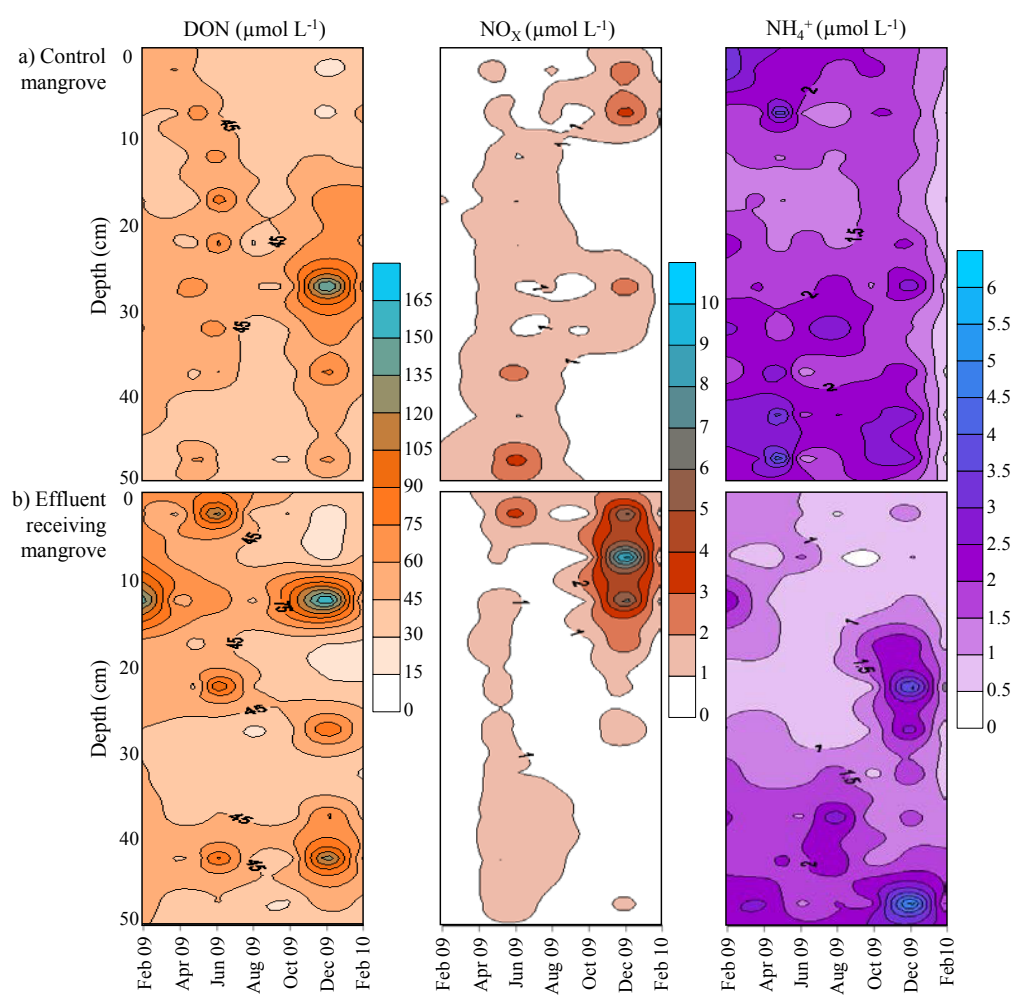

Figure 7: Temporal and depth evolution of the concentrations in $\mathrm{DON}, \mathrm{NO}_{x}$ and $\mathrm{NH}_{4}^{+}$(means of tree replicates) in pore-waters in the control mangrove (a) and in the effluent receiving mangrove (b). Graphical representation was performed under Surfer 8, with Krigging interpolation method for extrapolating values between sampling periods.

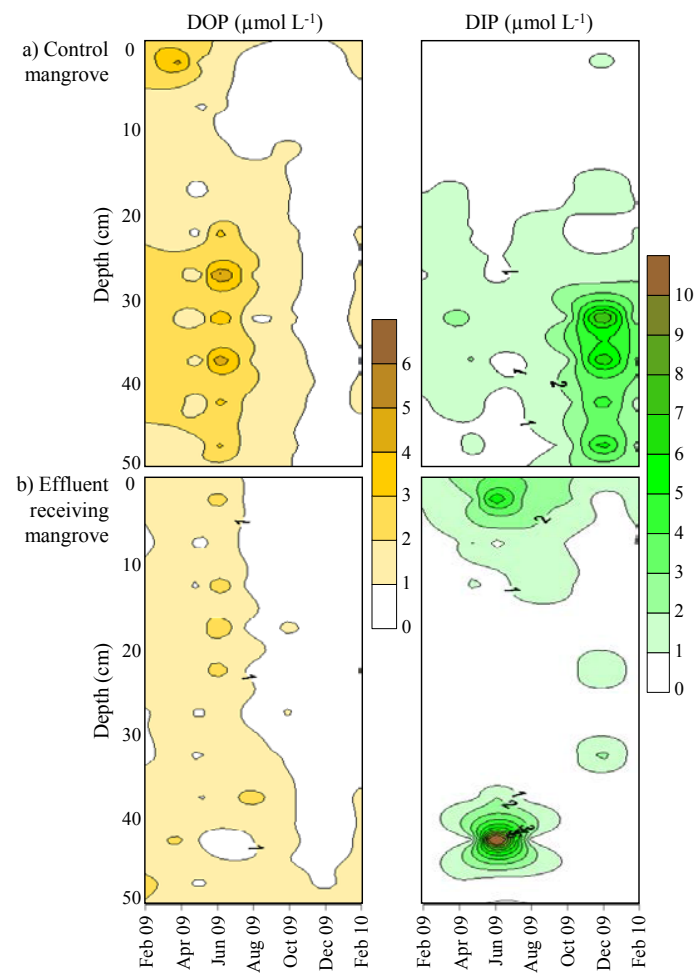

Figure 8: Temporal and depth evolution of the concentrations in DOP and DIP (means of tree replicates) in pore-waters in the control mangrove (a) and in the effluent receiving mangrove (b). Graphical representation was performed under Surfer 8, with Krigging interpolation method for extrapolating values between sampling periods. 
pore-water. The absence of root should contribute to the maintenance of concentration between 1 and $10 \mu \mathrm{mol.L^{-1 }}$ in pore-waters at depth.

Seasonal evolution of pore-waters in the effluent receiving mangrove: Within the effluent receiving mangrove, pore-water salinity evolution with depth and along the year was similar to the one in the control mangrove (Figure 5). However, during the active period of the farm, a dilution characterized the upper sediment, with values close to 35 , same that the lagoon water and 10 units lower than the pore-water of the control mangrove. In addition, the water content of the effluent receiving mangrove was slightly higher than for the control one $(64 \%$ vs. $56 \%$ ). The fact that releasing effluent in the mangrove led to a decrease of pore-water salinity may induce ecological modifications of the ecosystem. Mangrove is a zoned ecosystem, and each mangrove plant develops under specific conditions. In New Caledonia, porewater salinity is a key driving factor of mangrove zonation [41]. Actually, Avicennia trees extend behind Rhizophora trees that develop on the seashore because they cannot cope with high pore-water salinities. Artificially decreasing salinity by releasing effluent may led to the development of favorable conditions for Rhizophora trees within the Avicennia stand, and the disappearance of the latter stand. This phenomenon was observed by many shrimp farmers downstream their ponds in New Caledonia. Nevertheless, during the non active period of the farm, salinity values returned to their normal values for this stand, and prevent the colonization by Rhizophora trees. In fact, salinity values were even higher than in the control one, probably as a result of the more develop root-system of Avicennia trees that led to higher transpiration processes. Surprisingly, mangrove sediments downstream the ponds were characterized by suboxic conditions almost during the whole year and on the whole depth profile, with Eh values higher than $50 \mathrm{mV}$ (Figure 5) and the presence of $\mathrm{Fe}^{2+}$ and $\mathrm{Fe}^{3+}$ down to $45 \mathrm{~cm}$ depth (Figure 6). In addition and opposite to the control mangrove, there was no stratification of the redox conditions with depth. Like for the salinity, the fact that trees were bigger downstream the ponds, and with a higher density, probably implied a more developed root system, and due to its physiological abilities, have induced a better oxygenation of the sediment. During the non active period of the farm, from August to February, Eh values were slightly lower (Figure 5). This period corresponds also to the beginning of the seasonal temperature increase. In the previous discussion concerning Chl-a seasonal evolution, this period was characterized by a bloom of microphytobenthos. Thus, the upper sediment was subjected to an increase input of organic matter that may have induced greater oxygen consumption for its decay. The most significant seasonal variation of the redox conditions was identified between 10 and $25 \mathrm{~cm}$ depth (WMW test, $p<0.05$ ), corresponding again to the root level. The fact that the Eh values at the root level were lower during summer may indicate that the production of labile OM from roots exudates stimulated bacterial processes. Consequently, the root system can influence the redox conditions in two ways: by releasing oxygen, leading to an increase of Eh values, and by the production of labile organic matter, leading to a decrease of Eh values. Downstream the biggest shrimp farm in New Caledonia (132 ha of ponds), previous results were contradictory, the sediment being anoxic for almost the whole depth profile during the period of effluent release, while oxidizing in the upper core during the period without effluent release [26]. In addition to the fact that the current study site was characterized by a smaller farm, with only two shrimp ponds, the farmer has decided to dig a channel to allow a better export of the effluents. This channel brings the effluents to the Rhizophora stand, which is closer to the sea. As a result, the effluents covered the Avicennia stand only when the channel overflows at high tide. The Avicennia stand is thus not always covered by a sheet of water like downstream the bigger farm. Rhizophora stands are characterized by a higher productivity, a close canopy, elevated organic content in their sediments, and anoxic conditions with sulfate reduction processes [62]. In addition, they are submerged at each tide. Releasing the effluents in the Rhizophora stand will not modify the pore-water salinity of the stand. Additionally, the latter is already organic rich and subject to sulfate reduction process. Eventually, the close canopy will limit the light intensity reaching the soil and thus the development of microphytobenthos. We suggest that releasing effluent in the Rhizophora stand would be a better option, preventing any ecological modification neither of the Avicennia stand nor the Rhizophora stand. Since the shrimp farm released high quantity of total $\mathrm{N}$ and $\mathrm{P}$, approximately 2.3 and 0.5 tons, respectively [44], we followed the concentrations of the different forms of dissolved $\mathrm{P}$ and $\mathrm{N}$ in the porewaters in the effluent receiving mangrove. Three main differences with the control mangrove were evidenced: i) DON concentrations were higher during the whole year and on almost the whole depth profile, ii) $\mathrm{NO}_{x}$ concentrations in the upper sediment were higher during the hottest months, and iii) $\mathrm{NH}_{4}^{+}$concentrations were lower in the upper sediment whatever the season (Figure 7). Higher DON concentrations may be related to the more developed root system and the higher OM input into the sediment compare to the control mangrove. In French Guiana, a strong increase of DOC concentrations in pore-waters with plant development was observed [79]. We identified that $\mathrm{N}$ and $\mathrm{P}$ inputs were mainly as organics forms [44]. This excess nitrogen load can be eliminate by benthic nitrogen cycling as gaseous products $\left(\mathrm{N}_{2}\right.$, $\mathrm{N}_{2} \mathrm{O}$ and $\mathrm{NO}$ ) via denitrification and anaerobic ammonium oxidation (anammox) [80-82]. In a previous study, we observed that nitrification in the sediment at the outlet of a pond was the predominant source of nitrate fuelling nitrate reduction processes; nitrification rate was up to $210.6 \pm 46.8 \mu \mathrm{mol} \mathrm{m}^{-2} \mathrm{~h}^{-1}[44]$. The high NOx content characterizing the upper sediment during summer and the absence of ammonium may result from marked $\mathrm{N}$ benthic processes. As evidenced by the Chl-a seasonal distribution, the beginning of the summer was characterized by intense bacterial activity. Concerning dissolved phosphorus, the organic forms presented the same distribution than the control mangrove, but with lower values (Figure 8). DOP concentrations were lower than $2 \mu \mathrm{mol} . \mathrm{L}^{-1}$ from February to August, and then under the detection limit. More intense decomposition processes resulting from the more developed root system may explain this trend. Concerning the inorganic form, we were not able to detect its presence in the upper sediment of the control mangrove probably as a result of its rapid utilization by mangrove trees and its possible precipitation with oxihydroxides. However in the effluent receiving mangrove, concentrations increased with farm activity, ranging between 1 and $5 \mu \mathrm{mol} . \mathrm{L}^{-1}$ (Figure 8), evidencing the influence of effluents on this limiting nutrient, which may be favorable to mangrove growth.

\section{Conclusion}

This study highlighted an effective impact of the discharge of shrimp farm effluents on benthic primary productivity at mangrove sediment surface, as well as on the physico-chemical processes in the pore-waters, even several months after the cessation of the release. However, we did not evidence any sign of saturation, eutrophication or anoxia of the effluent receiving mangrove, probably as a result of, on the one hand, the physiological abilities of the root system to aerate the sediment, and on the other hand, the construction of a channel that conducts the effluents directly to the Rhizophora stand limiting the dispersing of the effluents within the Avicennia stand at the high tide periods. The main conclusions of this study can be summarized as followed. 
Citation: Molnar N, Marchand C, Deborde J, Della Patrona L, Meziane T (2014) Seasonal Pattern of the Biogeochemical Properties of Mangrove Sediments receiving Shrimp Farm Effluents (New Caledonia). J Aquac Res Development 5: 262. doi:10.4172/2155-9546.1000262

- Quality and quantity of the organic matter at sediment surface strongly differed between the two mangroves. POC and Chl-a concentrations were higher at sediment surface in the effluent receiving mangrove, while $\mathrm{C} / \mathrm{N}$ values were lower, indicating a greater algae development and a higher primary productivity as a result of nutrients input from the shrimp ponds.

- Chl-a concentrations increased during summer, which is the hot and wet season, reflecting a greater development of microphytobenthos. The activity of the latter at sediment surface in the Avicennia stand was driven both by the release of effluent and the climatic seasonal evolution. The fact that the final drain of the shrimp ponds occurred just before the seasonal temperature increase induced a boosted algal bloom, and the fact the sediment never recovered its natural characteristics.

- Organic enrichment of the effluent receiving mangrove sediment was moderated compared to other mangrove swamps, and there were not significant differences with the control mangrove. However, the higher density and much greater individual size of the mangrove trees were translated by a higher contribution of their debris in the sedimentary organic pool.

- Releasing effluents in the mangrove led to a decrease of porewater salinity during the active period of the farm. However during the non active period of the farm, salinity values returned to their normal values for this stand, and prevent the colonization by Rhizophora trees, limiting ecological modification of the ecosystem.

- Surprisingly, mangrove sediments downstream the ponds were characterized by suboxic conditions almost during the whole year and on the whole depth profile. In addition and opposite to the control mangrove, there was no stratification of the redox conditions with depth up to $50 \mathrm{~cm}$. The fact that trees were bigger downstream the ponds, with a higher density, probably implied a more developed root system, and due to its physiological ability, have induced a better oxygenation of the sediment.

- Concerning nitrogen cycling, higher DON concentrations were measured probably as a result of the higher mangrove trees development. In addition, the upper sediment of the effluent receiving mangrove was characterized by higher $\mathrm{NO}_{x}$ concentrations and lower $\mathrm{NH}_{4}^{+}$concentrations, evidencing more intense benthic $\mathrm{N}$ processes, notably nitrification as a result of the better oxygenation of the sediment.

\section{Acknowledgement}

This work was supported by the ZONECO Program, the Northern Province and Southern Province of New Caledonia. We thank the staff of the FAO farm that made this project possible by allowing us to access to the ponds, farm data and to the adjacent mangrove. We thank the staff of the IFREMER, Saint Vincent station for their valuable help, in particular Benoit Bellief. We thank Audrey Leopold for her assistance with field and laboratory work, and Phillipe Gerard (Laboratoire de Chimie Marine) from IRD for chemical analysis. Eventually, Dave Welsh is thanked for fruitful discussion on data analysis.

\section{References}

1. Duke NC, Ball MC, Ellison JC (1998) Factors Influencing Biodiversity and Distributional Gradients in Mangroves. Global Ecology and Biogeography 7: 27-47.

2. Giri C, Ochieng E, Tieszen LL, Zhu Z, Singh A, et al. (2010) Status and distribution of mangrove forests of the world using earth observation satellite data. Global Ecology and Biogeography 20: 154-159.
3. Barbier EB (2007) Valuing ecosystem services as productive inputs. Economic Policy 22: 177-229.

4. Lee SY, Primavera JH, Dahdouh-Guebas F, McKee K, Bosire J, et al. (2014) Redefining the ecological role and services of tropical mangrove ecosystems. Journal of Global Ecology and Biogeography 23: 726-743.

5. Rönnbäck P, Kautsky N, Pihl L, Troell M, Söderqvist T, et al. (2007) Ecosystem goods and services from Swedish coastal habitats: identification, valuation and implications of ecosystem shifts. AMBIO: a Journal of the Human Environment 36: 534-544.

6. Furukawa K, Wolanski E, Mueller H (1997) Currents and sediment transport in mangrove forests. Estuarine Coastal and Shelf Science 44: 301-310.

7. Wells S, Ravilous C, Corcoran E (2006) In the Front Line: Shoreline Protection and Other Ecosystem Services from Mangroves and Coral Reefs. United Nations Environment Programme World Conservation Monitoring Centre, Cambridge, UK 33.

8. Walters BB, Ronbäck P, Kovacs JM, Crona B, Hussain SA, et al. (2008) Ethnobiology, socioeconomics and management of mangrove forests: a review. Aquatic Botany 89: 220-236.

9. Spalding M (1997) The global distribution and status of mangrove ecosystems International News Letter of Coastal Management-Intercoast Network, Specia edition 1: 20-21.

10. Duke NC, Meynecke JO, Dittmann S, Ellison AM, Anger K, et al. (2007) A world without mangroves? Science 317: 41-42.

11. UNEP-WCMC (2006) In the front line: shoreline protection and other ecosystem services from mangroves and coral reefs. UNEP-WCMC, Cambridge, UK.

12. Valiela I, Bowen JL, York JK (2001) Mangrove Forests: One of the World's Threatened Major Tropical Environments. Bio Science 51: 807-815.

13. Wilkie ML, Fortuna S (2003) Status and trends in mangrove area exten worldwide. Working Paper FRA 63, Forest Resources Division, Forestry Department, UN-Food and Agriculture Organization, 292.

14. Alongi DM (2002) Present state and future of the world's mangrove forests Environmental Conservation 29: 331-349.

15. Bostock J, McAndrew B, Richards R, Jauncey K, Telfer T, et al. (2010) Aquaculture: global status and trends. Philosophycal Transactions of the Royal Society B-Biological Sciences 365: 2897-2912.

16. Menasveta $\mathrm{P}$ (1997) Mangrove destruction and shrimp culture systems. World Aquaculture 28: 36-42

17. Paez-Osuna $F$ (2001) The environmental impact of shrimp aquaculture: causes, effects, and mitigating alternatives. Environmental Management 28: 131-140.

18. Jackson C, Preston N, Thompson P, Burford M (2003) Nitrogen budget and effluent nitrogen components at an intensive shrimp farm. Aquaculture 218: 397-411.

19. Thomas Y, Courties C, El Helwe Y, Herbland A, Lemonnier H (2010) Spatial and temporal extension of eutrophication associated with shrimp farm wastewater discharges in the New Caledonia lagoon. Mar Pollut Bull 61: 387-398.

20. Avnimelech Y, Ritvo G (2003) Shrimp and fish pond soils: processes and management. Aquaculture 220: 549-567.

21. Della Patrona L, Brun $P$ (2009) The Culture of blue shrimp in New-Caledone. Litopenaeus stylirostris. Bases biologiques et zootechnie. Ifremer.

22. Costanzo SD, O'Donohue MJ, Dennison WC (2004) Assessing the influence and distribution of shrimp pond effluent in a tidal mangrove creek in North-East Australia. Mar Pollut Bull 48: 514-525.

23. Burford MA, Costanzo SD, Dennison WC, Jackson CJ, Jones A, et al. (2003) A synthesis of dominant ecological processes in intensive shrimp ponds and adjacent coastal environments in NE Australia. Mar Pollut Bull 46: 1456-1469.

24. McKinnon AD, Trott LA, Alongi DM, Davidson A (2002) Water column production and nutrient characteristics in mangrove creeks receiving shrimp farm effluent. Aquaculture Research 33: 55-73.

25. Trott LA, Alongi DM (2000) The impact of shrimp pond effluent on water quality and phytoplankton biomass in a tropical mangrove estuary. Mar Pollut Bull 40 947-951.

26. Marchand C, Lallier-Vergès E, Allenbach M (2011a) Redox conditions and heavy metals distribution in mangrove forests receiving effluents from shrimp 
Citation: Molnar N, Marchand C, Deborde J, Della Patrona L, Meziane T (2014) Seasonal Pattern of the Biogeochemical Properties of Mangrove Sediments receiving Shrimp Farm Effluents (New Caledonia). J Aquac Res Development 5: 262. doi:10.4172/2155-9546.1000262

Page 12 of 13

farm effluents (Teremba bay, New Calodenia). J Soils and Sediments 11: 529541

27. Trott LA, McKinnon AD, Alongi DM, Davidson A, Burford MA (2004) Carbon and nitrogen processes in a mangrove creek receiving shrimp farm effluent. Estuarine, Coastal and Shelf Science 59: 197-207.

28. Virly S, Buisson D, Clough D, Lemmonier H, Richer de Forges B (2005) Evaluation de l'impact de l'aquaculture de crevettes sur les mangroves de Nouvelle- Calédonie. Rapport final. Pgm ZoNeCo.

29. Song J, Luo YM, Zhao QG, Christie P (2003) Novel use of soil moisture samplers for studies on anaerobic ammonium fluxes across lake sedimentwater interfaces. Chemosphere 50: 711-715.

30. Yentsch CS, Menzel DW (1963)A method for the determination of phytoplankton chlorophyll and phaeophytin by fluorescence. Deep-Sea Research 10: 221231.

31. Vismann B (1996) Sulphide exposure experiments: the sulphide electrode and a set-up automatically controlling sulphide, oxygen and $\mathrm{pH}$. Journal of Experimental Marine Biology and Ecology 204: 131-140.

32. Marchand C, Baltzer F, Lallier-Vergès E, Albéric P (2004) Pore-water chemistry in mangrove sediments: relationship with species composition and developmental stages (French Guiana). Marine geology 208: 361-381.

33. Stookey LL (1970) Ferrozine A new spectrophotometric reagent for iron. Analytica Chemica Acta 42: 779-781.

34. Rodier J (1976) L'analyse de l'eau, eaux naturelles, eaux résiduaires, eau de mer. Dunod, Paris.

35. Holmes RM, Aminot A, Kerouel R, Hooker BA, Peterson BJ (1999) A simple and precise method for measuring ammonium in marine and freshwater ecosystems. Canadian Journal of Fisheries and Aquatic Sciences 56: 18011808.

36. Bendschneider K, Robinson RJ (1952) A new spectrophotometric method for the determination of nitrite in sea water. Journal of Marine Research 11: 87-96.

37. Murphy J, Riley JP (1962) A modified single solution method for determination of phosphate in natural waters. Analytica Chimica Acta 27: 31-36.

38. Lafargue E, Marquis F, Pillot D (1998) Rock-Eval 6 applications in hydrocarbon exploration, production and soil contamination studies. Revue de l'Institut français du Pétrole 53: 421-437.

39. Marchand C, Lallier-Verges E, Disnar J-R, Keravis D (2008) Organic carbon sources and transformations in mangrove sediments: A Rock-Eval pyrolysis approach. Organic Geochemistry 39: 408-421.

40. Virly S (2008) Atlas des mangroves de Nouvelles-Caledonie, France.

41. Marchand C, Allenbach M, Lallier-Verges E (2011b) Relationships between heavy metals distribution and organic matter cycling in mangrove sediments (Conception Bay, New Caledonia). Geoderma 160: 444-456.

42. Walsh GE (1974) Mangroves, a review. In: Reimold RJ, Queens WH edn Ecology of Halophytes. Academic Press, 51-174.

43. Mckee KL (1993) Soil Physicochemical Patterns and Mangrove species Distribution, Reciprocal Effects? Journal of Ecology 81: 477-487.

44. Molnar N, Welsh DT, Marchand C, Deborde J, Meziane T (2013) Impacts of shrimp farm effluents on water quality, benthic metabolism and N-dynamics in a mangrove forest (New Caledonia). Estuarine Coastal and Shelf Sciences 117: $12-21$.

45. Robertson Al, Phillips MJ (1995) Mangroves as filters of shrimp pond effluent: predictions and biogeochemical research needs. Hydrobiologia 295: 311-321.

46. Donato DC, Kauffman JB, Murdiyarso D, Kurnianto S, Stidham M, et al. (2011) Mangroves among the most carbon-rich forests in the tropics. Nature Geoscience 4: 293-297.

47. Kristensen E, Bouillon S, Dittmar T, Marchand C (2008) Organic carbon dynamics in mangrove ecosystem. Aquatic Botany 89: 210-219.

48. Alongi DM (1994) Zonation and seasonality of benthic primary production and community respiration in tropical mangrove forests. Oecologia 98: 320-327.

49. Alongi DM, Sasekumar A (1992) Benthic Communities. In Tropical mangrove ecosystem, Robertson Al, Alongi DM. American Geophysical union, 137-170.

50. Wooller M, Smallwood B, Jacobson M, Fogel M (2003) Carbon and nitrogen stable isotopic variation in Laguncularia racemosa (L.) (white mangrove) from Florida and Belize: implications for trophic level studies. Hydrobiologia 499: 13-23.

51. Leopold A, Marchand C, Deborde J, Chaduteau C, Allenbach M (2013) Influence of mangrove zonation on $\mathrm{CO} 2$ fluxes at sediment-air interface (NewCaledonia). Geoderma 202-203: 62-70.

52. Bouillon S, Koedam N, Raman AV, Dehairs F (2002) Primary producers sustaining macro-invertebrate communities in intertidal mangrove forests. Oecologia 130: 441-448.

53. Clavier J, Garrigue C (1999) Annual sediment primary production and respiration in a large coral reef lagoon (SW New Caledonia). Marine Ecology Progress Series 191: 79-89.

54. Alongi DM (1988) Bacterial productivity and microbial biomass in tropica mangrove sediments. Microbial Ecology 15: 59-79.

55. Meziane T, Tsuchiya M (2002) Organic matter in a subtropical mangroveestuary subjected to wastewater discharge: Origin and utilization by two macrozoobenthic species. Journal of Sea Research 47: 1-11.

56. Sam R, Ridd $P$ (1998) Spatial variations of groundwater salinity in a mangrove salt-flat system, Cocoa Creek, Australia. Mangroves and Salt Marshes 2: $121-$ 132.

57. Ridd PV (1996) Flow through animal burrows in mangrove creek. Estuarine Coastal and Shelf Sciences 43: 617-625.

58. de Vos JA, Raats PAC, Fedes RA (2002) Chloride transport in a recently reclaimed Dutch polder. Journal of Hydrology 257: 59-77.

59. Webster IT, Norquay, SJ, Ross FC, Wooding RA (1996) Solute exchange by convection within estuarine sediments. Estuarine, Coastal and Shelf Science 42: 171-183.

60. Alongi DM, Sasakumar A, Tirendi F, Dixon P (1998) The influence of stand age on benthic decomposition and recycling of organic matter in managed mangrove forests of Malaysia. Journal of Experimental Marine Biology and Ecology 225: 197-218.

61. Marchand C, Lallier-Vergès E, Baltzer F, Alberic P, Cossa D, et al. (2006) Heavy metals distribution in mangrove sediments along the mobile coastline of French Guiana. Marine chemistry 98: 1-17.

62. Marchand C, Fernandez J-M, Moreton B, Landi L, Lallier-Vergès E, et al. (2012) The partitioning of transitional metals $(\mathrm{Fe}, \mathrm{Mn}, \mathrm{Ni}, \mathrm{Cr}$ ) in mangrove sediments downstream of a ferralitised ultramafic watershed (New Caledonia). Chemical Geology 300-301: 70-80.

63. Kristensen E (2008) Mangrove crabs as ecosystem engineers; with emphasis on sediment processes. Journal of Sea Research 59: 30-43.

64. Alongi DM, Tirendi F, Clough BF (2000) Below-ground decomposition of organic matter in forests of the mangroves Rhizophora stylosa and Avicennia marina along the arid coast of Western Australia. Aquatic Botany 68: 97-122.

65. Clark MW, McConchie D, Lewis DW, Saenger P (1998) Redox stratification and heavy metal partitioning in Avicennia-dominated mangrove sediments: a geochemical model. Chemical Geology 149: 147-171.

66. Naidoo G, Rogalla H, Von Willert DJ (1997) Gas exchange responses of a mangrove species, Avicennia marina, to waterlogged and drained conditions. Hydrobiologia 352: 39-47.

67. Thibodeau FR, Nickerson NH (1986) Differential oxidation of mangrove substrate by Avicennia germinans and Rhizophora mangle. American Journal of Botany 73: 512-516.

68. Scholander PF, Van dam L, Scholander SI (1955) Gas exchange in the roots of mangrove. American Journal of Botany 42: 92-98.

69. Marchand C, Lallier-Vergès E, Baltzer F (2003) The composition of bulk sedimentary organic matter in relation to the dynamic features of a mangrovefringed coast in French Guiana. Estuarine Coastal and Shelf Sciences 56: 119130.

70. Noël V, Marchand C, Juillot F, Ona-Nguema G, Viollier E, et al. (In press). EXAFS analysis of iron cycling in mangrove sediments downstream a lateritized ultramafic watershed (Vavouto Bay, New Caledonia). Geochimica et Cosmochimica Acta 136: 211-228.

71. Conant RT, Ryan MG, Agren GI, Birge HE, Davidson EA, et al. (2011) 
Citation: Molnar N, Marchand C, Deborde J, Della Patrona L, Meziane T (2014) Seasonal Pattern of the Biogeochemical Properties of Mangrove Sediments receiving Shrimp Farm Effluents (New Caledonia). J Aquac Res Development 5: 262. doi:10.4172/2155-9546.1000262

Temperature and soil organic matter decomposition rates-synthesis of current knowledge and a way forward. Global Change Biology 17: 3392-3404.

72. Arfi Y, Marchand C, Wartel M, Record E (2012) Fungal diversity in anoxicsulfidic sediments in a mangrove soil. Fungal Ecology 5: 282-285.

73. Mackey AP, Smail G (1995) Spatial and temporal variation in litter fall of Avicennia marina (Forssk) vierh in the Brisbane-River, Queensland, Australia. Aquatic Botany 52: 133-142.

74. Bouillon S, Borges AV, Castañeda-Moya E, Diele K, Dittmar T, et al. (2008) Mangrove production and carbon sinks: a revision of global budget estimates. Globalal Biogeochemical Cycling 22

75. Ferreira TO, Otero XL, Vidal-Torrado P, Macias F (2007) Effects of bioturbation by root and crab activity on iron and sulfur biogeochemistry in mangrove substrate. Geoderma 142: 36-46.

76. Clough B (1992) Primary productivity and growth of mangrove forest. Tropical Mangrove Ecosystems, Union A.G. editor, 225-249.
77. Alongi DM (1996) The dynamics of benthic nutrient pools and fluxes in tropical mangrove forests. Journal of Marine Research 54: 123-148.

78. Deborde J, Anschutz P, Chaillou G, Etcheber H, Commarieu MV, et al. (2007) The dynamics of phosphorus in turbid estuarine systems: Example of the Gironde estuary (France). Limnology and Oceanography 52: 862-872.

79. Marchand C, Albéric P, Lallier-Vergès E, Baltzer F (2006) Distribution and characteristics of dissolved organic matter in mangrove sediment pore-waters along the coastline of French Guiana. Biogeochemistry 81: 59-75.

80. Herbert RA (1999) Nitrogen cycling in coastal marine ecosystems. FEMS Microbiology Reviews 23: 563-590.

81. Dalsgaard T, Thamdrup B, Canfield DE (2005) Anaerobic ammonium oxidation (Anammox) in the marine environment. Research in Microbiology 156: 457 464

82. Thornton DCO, Dong LF, Underwood GJC, Nedwell BD (2007) Sediment-water inorganic nutrient exchange and nitrogen budgets in the Colne Estuary, UK. Marine Ecology Progress Series 337: 63-77. 